\title{
Sustained Arc/Arg3.1 Synthesis Controls Long-Term Potentiation Consolidation through Regulation of Local Actin Polymerization in the Dentate Gyrus In Vivo
}

\author{
Elhoucine Messaoudi, Tambudzai Kanhema, ${ }^{*}$ Jonathan Soulé, ${ }^{\star}$ Adrian Tiron, ${ }^{\star}$ Girstaute Dagyte, Bruno da Silva, and \\ Clive R. Bramham \\ Department of Biomedicine and Bergen Mental Health Research Center, University of Bergen, N-5009 Bergen, Norway
}

\begin{abstract}
New gene expression is necessary for long-term potentiation (LTP) consolidation, yet roles for specific activity-induced mRNAs have not been defined. Here we probed the dynamic function of activity-induced Arc (activity-regulated cytoskeletal-associated protein)/Arg3.1 (activity-regulated gene 3.1 protein homolog) mRNA using brief, local infusions of antisense (AS) oligodeoxynucleotides at multiple time points during dentate gyrus LTP in vivo. Surprisingly, early Arc synthesis is necessary for early expression of LTP, whereas sustained synthesis is required to generate stably modified synapses. AS application $2 \mathrm{~h}$ after LTP induction results in a rapid and permanent reversal of LTP. This reversal is associated with rapid knockdown of upregulated Arc, dephosphorylation of actin depolymerization factor/cofilin, and loss of nascent filamentous actin (F-actin) at synaptic sites. Infusion of the F-actin stabilizing drug jasplakinolide during LTP maintenance blocks the ability of AS to reverse LTP. These results couple activity-induced expression of Arc to expansion of the actin cytoskeleton underlying enduring LTP. Furthermore, Arc synthesis is required for both the induction and consolidation of LTP elicited by local BDNF infusion, thus identifying Arc as a key molecular effector of BDNF in synaptic plasticity.
\end{abstract}

Key words: synaptic plasticity; long-term potentiation; immediate early gene; protein synthesis; actin; brain-derived neurotrophic factor; neurotrophins; hippocampus

\section{Introduction}

Activity-dependent changes in synaptic strength are implicated in a range of adaptive brain responses, including memory formation, mood stability, and drug addiction (Hyman et al., 2006; Kuipers and Bramham, 2006; Morris, 2006; Nestler and Carlezon, 2006). Persistent changes in synaptic strength, as seen during long-term potentiation (LTP), require new gene expression and protein synthesis (Frey et al., 1996; Nguyen and Kandel, 1996; Bliss et al., 2007). The classical distinction between early- and late-phase LTP is based on the sensitivity of the latter to broadspectrum inhibitors of gene expression and protein synthesis. However, the function of individual mRNA species in the process of LTP consolidation is not well understood. LTP is associated with the induction of a variety of immediate early genes, and knock-outs of several of these genes, including the zinc-finger transcription factor zif268/egrl (early growth response 1), tissue plasminogen activator, and Arc (activity-regulated cytoskeletonassociated protein) [also known as Arg3.1 (activity-regulated gene 3.1 protein homolog)], have defects in LTP maintenance

\footnotetext{
Received Jan. 5, 2007; revised July 25, 2007; accepted Aug. 3, 2007.

This work was funded by the Norwegian Research Council and European Union Biotechnology Program Grant B104-CT98-0333. BDNF was provided by Amgen-Regeneron Partners.

*T.K., J.S., and A.T. contributed equally to this work.

Correspondence should be addressed to Dr. Clive Bramham, Department of Biomedicine, University of Bergen, Jonas Lies vei 91, N-5009 Bergen, Norway. E-mail: clive.bramham@biomed.uib.no. DOI:10.1523/JNEUROSCI.2883-07.2007

Copyright $\odot 2007$ Society for Neuroscience $\quad$ 0270-6474/07/2710445-11\$15.00/0
}

and/or memory consolidation (Huang et al., 1996; Jones et al., 2001; Plath et al., 2006). Although gene deletion and knockdown studies give insight into overall gene function, alternative methods are required to resolve the dynamic actions of activityinduced mRNAs after LTP induction.

A specialized role of Arc in synaptic plasticity is implied by the fact that Arc mRNA is rapidly transported to dendritic processes in which it undergoes local translation (Link et al., 1995; Lyford et al., 1995; Steward and Worley, 2001a). Here, we used brief, local infusions of Arc antisense oligodeoxynucleotides (AS-ODNs) to delineate the function of newly induced Arc mRNA during LTP in the dentate gyrus of anesthetized rats. We show that Arc synthesis defines a novel time window in LTP maintenance, during which early Arc synthesis is necessary for expression of LTP, whereas sustained synthesis is required to generate stably modified synapses. In addition to de novo gene expression, recent work suggests that LTP consolidation requires actin polymerizationdependent expansion of the postsynaptic density (PSD) and dendritic spine (Fukazawa et al., 2003; Matsuzaki et al., 2004; Zito et al., 2004). Arc is known to cosediment with crude filamentous actin (F-actin) and localize to the PSD of excitatory synapses (Lyford et al., 1995; Husi et al., 2000; Donai et al., 2003; Plath et al., 2006). Here, we show that acute inhibition of Arc synthesis at $2 \mathrm{~h}$ after LTP induction induces loss of nascent F-actin at synaptic sites and dephosphorylation of cofilin, a major regulator of actin dynamics. Thus, Arc couples two central tenets of LTP consolidation: activity-induced gene expression and regulation of local 
actin polymerization. Several lines of evidence suggest that LTP consolidation is activated by the secretory peptide brain-derived neurotrophic factor (BDNF) (Bramham and Messaoudi, 2005). We report that Arc synthesis is necessary for the induction and time-dependent consolidation of LTP elicited by BDNF application, thus identifying Arc as a molecular effector for BDNF in synaptic plasticity.

\section{Materials and Methods}

Electrophysiology and intrahippocampal infusion. Data were obtained from 189 male Sprague Dawley urethane-anesthetized $(1.4-1.8 \mathrm{~g} / \mathrm{kg}$, i.p.) rats weighing $250-320 \mathrm{~g}$. Stereotaxic coordinates relative to bregma were $7.9 \mathrm{~mm}$ posterior, $4.2 \mathrm{~mm}$ lateral for stimulation, $3.9 \mathrm{~mm}$ posterior, and $2.2 \mathrm{~mm}$ lateral for recording. An outer (guide) cannula (24 gauge; Plastics One, Roanoke, VA) was beveled sharp at the tip to facilitate tissue penetration. A Teflon-coated stainless steel wire recording electrode (coated diameter of $112 \mu \mathrm{m}$ ) was glued (cyanoacrylate, Mega-G base; Mega Metal, Oslo, Norway) to the shaft of the outer cannula. The electrode was then cut so that it extended $900 \mu \mathrm{m}$ from the end of the cannula. A concentric bipolar stimulating electrode (tip separation, 500 $\mu \mathrm{m}$; SNEX 100; Rhodes Medical Instruments, Woodland Hills, CA) was lowered into the dorsomedial aspect of the angular bundle for stimulation of the medial perforant path. After making a small slit in the dura, the guide cannula and attached recording electrode was slowly lowered into the dorsal hippocampus until a positive-going field EPSP (fEPSP) of maximum slope was obtained in the dentate hilus. The final depth of the recording electrode ranged between 200 and $300 \mu \mathrm{m}$ below the level of the maximum negative-going fEPSP sink recorded in the middle third of the dentate molecular layer. An inner infusion cannula (31 gauge) was then inserted so that it protruded $300 \mu \mathrm{m}$ below the end of the guide. The tip of the infusion cannula was located in deep stratum lacunosummoleculare of field CA1, $700 \mu \mathrm{m}$ above the hilar recording site and $300-400 \mu \mathrm{m}$ above the medial perforant synapses.

Biphasic rectangular pulses of $150 \mu$ s duration were applied every $30 \mathrm{~s}$ throughout the experiment. The stimulation intensity for test pulses was set to elicit a population spike amplitude of $30 \%$ of the maximal response. The infusion cannula was connected via PE50 polyethylene tubing to a $5 \mu \mathrm{l}$ Hamilton syringe. Solutions were delivered by an infusion pump at a rate of $80 \mathrm{nl} / \mathrm{min}$. BDNF-LTP was induced by infusing BDNF ( $2 \mu \mathrm{g}$ in $2 \mu \mathrm{l}$ of PBS) for $25 \mathrm{~min}$. The paradigm for high-frequency stimulation (HFS)-LTP induction consisted of eight pulses at $400 \mathrm{~Hz}$, repeated four times, at $10 \mathrm{~s}$ intervals. Three sessions of HFS were given at intervals of $5 \mathrm{~min}$.

Signals from the dentate hilus were amplified, filtered $(1 \mathrm{~Hz}$ to 10 $\mathrm{kHz})$, and digitized $(25 \mathrm{kHz})$. Acquisition and analysis of field potentials were accomplished using DataWave Technologies (Longmont, CO) WorkBench software. The maximum slope of the fEPSP and the amplitude of the population spike measured from its negative-going apex to the tangent line joining the first two positive peaks were measured, and averages of four consecutive responses were obtained. ANOVA for repeated measures followed by a post hoc Scheffe's test was used for statistical analysis of group effects. Statistics were based on values obtained during the $5 \mathrm{~min}$ at the end of baseline and at the end of postinfusion recording.

Oligodeoxynucleotides. Chimeric ODNs containing phosphorothioate linkages between the three bases on the $5^{\prime}$ and $3^{\prime}$ ends and phosphodiester internal linkages were synthesized, HPLC purified, ultrafiltrated, and sterilized (Biognostik, Göttingen, Germany). The main Arc ASODN used was directed against a 20-mer sequence (bases 209-228) covering the Arc start site. Scrambled (SC) Arc ODN containing the same base composition in randomized order served as control. A second ASODN targeting a nonoverlapping region of the Arc coding region (bases 943-960) was designed and manufactured by Biognostik. ODNs did not contain motifs such as G-quartets, kinase domains, or zinc fingers, and search of the European Molecular Biology Laboratory databases revealed no potential off-target genes (with significant homology and open secondary structure).

Drugs and antibodies. Human recombinant met-BDNF (a gift from
Amgen-Regeneron Partners, Tarrytown, NY) was obtained as a concentrated stock solution $(1.0 \mathrm{mg} / \mathrm{ml})$ in PBS $(150 \mathrm{~mm} \mathrm{NaCl}, 10 \mathrm{~mm}$ sodium phosphate buffer, $\mathrm{pH}$ 7.0, and $0.004 \%$ Tween 20). Jasplakinolide was dissolved in DMSO. Cycloheximide and anisomycin (Sigma, St. Louis, $\mathrm{MO}$ ) were dissolved in saline, and the anisomycin solution was adjusted to $\mathrm{pH} 7.4$

Primary antibodies used for immunoblotting were as follows: Arc N terminus (E-19: sc-6382 goat polyclonal IgG, 1:100; Santa Cruz Biotechnology, Santa Cruz, CA), Arc amino acids 1-300 (H300, sc-15325, rabbit polyclonal, 1:200; Santa Cruz Biotechnology), $\beta$-actin (clone AC-15, mouse monoclonal, 1:5000; Sigma), $\alpha$-subunit of calcium/calmodulindependent protein kinase II ( $\alpha$-CaMKII) (clone 6G9, mouse monoclonal, 1:2000; Affinity BioReagents, Golden, CO), PSD-95 (mouse IgG1, 1:500; BD Transduction Laboratories, Lexington, KY), phospho-cofilin (Ser-3) (sc-12912, 1:1000; Santa Cruz Biotechnology), cofilin (C-8736, 1:1000; Sigma), gelsolin (C-20, 1:200; Santa Cruz Biotechnology), profilin-1 (N-20, 1:200; Santa Cruz Biotechnology), $\alpha$-spectrin (AB992, 1:200; Chemicon, Temecula, CA).

Tissue microdissection and sample preparation. At the end of electrophysiological recording, rats were decapitated, and the brain was removed and rinsed with oxygenated ice-cold artificial CSF (in mM: 124.0 $\mathrm{NaCl}, 25.0 \mathrm{NaHOC}_{3}, 10.0$ D-glucose, $3.4 \mathrm{KCl}, 1.2 \mathrm{KH}_{2} \mathrm{PO}_{4}, 1.0 \mathrm{MgSO}_{4}$, and $2.5 \mathrm{CaCl}_{2}, \mathrm{pH} 7.4$ ). The hippocampus was then removed, and the dentate gyrus was resected on ice. The entire procedure took $<5 \mathrm{~min}$. Tissues were hand homogenized with 15 strokes in $300 \mu$ l of Dynal (Oslo, Norway) lysis/binding buffer.

SDS-PAGE and Western blotting. Protein levels in homogenate samples were determined using the Lowry method. Equal amounts of protein were loaded onto SDS-PAGE gels (10\%) and run overnight at constant $10 \mathrm{~mA}$. Separated proteins were transferred to a nitrocellulose membrane (Hybond-C; GE Healthcare, Little Chalfont, UK) at a constant voltage of $30 \mathrm{~V}$ overnight or $100 \mathrm{~V}$ for $1 \mathrm{~h}$. Membranes were blocked on a gyro-rocker for $1 \mathrm{~h}$ at room temperature (RT). Blocking buffer (BB) consisted of TBST (Tris-buffered saline/0.1\% Tween 20) and 5\% BSA. For $\alpha$-CaMKII, membranes were blocked $1 \mathrm{~h}$ at $37^{\circ} \mathrm{C}$. The primary antibodies were dissolved in BB containing 3\% BSA, and the blots incubated for $2 \mathrm{~h}$ at RT or $4^{\circ} \mathrm{C}$ overnight with constant shaking. After three washes with TBST, blots were incubated for $1 \mathrm{~h}$ in horseradish peroxidaseconjugated secondary antibody dissolved in TBST. The blots were washed three times with TBST, and proteins were visualized using enhanced chemiluminescence (ECL Western Blotting Analysis System; GE Healthcare). Blots were stripped with $100 \mathrm{~mm}$ 2-mercaptoethanol, 2\% SDS, and $62.5 \mathrm{~mm}$ Tris- $\mathrm{HCl}, \mathrm{pH} 6.7$, at $60^{\circ} \mathrm{C}$ for $1 \mathrm{~h}$ and reprobed with another antibody detecting the protein of interest. Optical density values obtained from the AS-treated dentate gyrus were normalized relative to values in the scrambled-treated or contralateral dentate gyrus. Statistical analyses were based on unpaired or paired $t$ tests as appropriate.

Preparation of sections. Animals were transcardially perfused with $4 \%$ paraformaldehyde in $0.1 \mathrm{~m}$ phosphate buffer (PB). Brains were dissected and postfixed in the fixative overnight at $4{ }^{\circ} \mathrm{C}$ and subsequently washed in $\mathrm{PB}$ containing $8 \%$ dextrose and $0.1 \%$ sodium azide. Coronal vibratome sections (50 $\mu \mathrm{m}$ thick) were stored in $0.1 \%$ sodium azide in $\mathrm{PB}$ at $4^{\circ} \mathrm{C}$. The same sections were used for in situ hybridization and immunohistochemistry.

In situ hybridization. RNA probes were prepared from a cDNA insert matching the first 2975 nucleotides of the Arc mRNA (GenBank accession number NM_019361) cloned into the pCRII-TOPO vector (Invitrogen, Oslo, Norway). Antisense and sense probes were transcribed from linearized plasmids using T7 and SP6 polymerase in the presence of digoxigenin (DIG) labeling mix according to the instructions of the manufacturer (Roche, Indianapolis, IN).

Floating sections were placed in PBS for 5 min, permeabilized with proteinase $\mathrm{K}(10 \mu \mathrm{g} / \mathrm{ml})$ for $5 \mathrm{~min}$ at $37^{\circ} \mathrm{C}$, and postfixed ( 5 min with $4 \%$ paraformaldehyde/PBS). After fixation, sections were treated with $0.25 \%$ acetic anhydride in $0.1 \mathrm{M}$ triethanolamine, $\mathrm{pH} 8$, for $10 \mathrm{~min}$, washed twice in $2 \times$ SSC, and placed for $10 \mathrm{~min}$ in a prehybridization buffer. Probes were applied to the sections, and hybridization was performed in a humidified chamber at $60^{\circ} \mathrm{C}$ for at least $16 \mathrm{~h}$. Sections were washed twice with $2 \times$ SSC at RT for $30 \mathrm{~min}$, once with $50 \%$ formamide in $2 \times$ SSC at 
$65^{\circ} \mathrm{C}$, rinsed in $2 \times \mathrm{SSC}$ at $37^{\circ} \mathrm{C}$, incubated with $20 \mu \mathrm{g} / \mathrm{ml} \mathrm{RNase} \mathrm{A}$ at $37^{\circ} \mathrm{C}$ for $30 \mathrm{~min}$, and incubated in RNase A buffer for at $65^{\circ} \mathrm{C}$ for $30 \mathrm{~min}$. After blocking in $2 \%$ blocking reagent for $1 \mathrm{~h}$ at RT, alkaline phosphatase-coupled anti-DIG antibody (1:2000; Roche) was applied. Visualization was done with the chromogenic substrates nitrobluetetrazolium-chloride and 5-bromo-4-chlor-indolyl-phosphate (Roche). Pictures were taken on a Nikon (Tokyo, Japan) Eclipse 80i microscope coupled to a Nikon DS-5M camera.

Immunohistochemistry. Sections were first treated with $\mathrm{PB}$ containing $100 \mathrm{~mm}$ glycine (Sigma), then washed in PBT (0.1\% Tween 20 in PB), incubated in $0.3 \% \mathrm{H}_{2} \mathrm{O}_{2}$ diluted in PBT, permeabilized for 20 min with $0.5 \%$ Triton X-100 diluted in PBT, rinsed, and immersed for $30 \mathrm{~min}$ in blocking buffer ( $4 \%$ BSA and 5\% horse serum in PBT). They were then incubated overnight at $4^{\circ} \mathrm{C}$ with the primary antibody diluted in blocking buffer. After three washes in PBT, biotinylated secondary antibody was applied for $1 \mathrm{~h}$ at RT. Sections were then washed in PBT, incubated in streptavidin-HRP diluted in PBT, washed in TBS, and finally processed for DAB staining.

Arc primary antibodies were $\mathrm{H} 300$ and a mouse anti-Arc monoclonal antibody from BD Biosciences (San Jose, CA) (catalog \#612602) raised against amino acids $1-300$ and $264-385$ of the Arc protein, respectively. Secondary antibodies were biotin-conjugated anti-rabbit or anti-mouse Ig (GE Healthcare). Streptavidin-conjugated HRP was obtained from GE Healthcare; diaminobenzidine $(1 \mathrm{mg} / \mathrm{ml}$; Sigma) was diluted in $0.1 \mathrm{M}$ Tris-buffered saline containing $\sim 0.03 \% \mathrm{H}_{2} \mathrm{O}_{2}$.

In vitro expression of Arc protein. The Arc coding region was amplified by PCR from rat hippocampal cDNA and cloned into the pcDNA3.1/V5His TOPO TA vector (Invitrogen). The resulting construct (pcDNA3.1/ Arc-V5-His) was transfected into human embryonic kidney HEK293FT cells using Lipofectamine 2000 (Invitrogen) according to the recommendations of the manufacturer. After $16 \mathrm{~h}$ at $37^{\circ} \mathrm{C}$, the cells were lysed in radioimmunoprecipitation assay buffer and centrifuged. The supernatant was then collected and processed for protein quantification using the BCA protein assay kit (Diagen, Rygge, Norway). Arc expression was detected by Western blotting using the same antibodies as for immunohistochemistry. Transfection control was achieved using pcDNA3.1/ V5His-TOPO/LacZ vector (Invitrogen).

Phalloidin staining. Sections were incubated in PBT containing 100 mM glycine (Sigma), washed with PBT, permeabilized in PBT containing $0.5 \%$ Triton $\mathrm{X}-100$, and rinsed three times for $10 \mathrm{~min}$. They were then incubated for at least $30 \mathrm{~min}$ with phalloidin-FITC $(0.1 \mu \mathrm{g} / \mathrm{ml}$; Sigma $)$ diluted in PBT containing 4\% BSA and 2\% horse serum. After several washes, sections were mounted in Vectashield (Vector Laboratories, Burlingame, CA). Pictures were acquired on a Zeiss (Oberkochen, Germany) AxioImager microscope.

Quantification of staining. Images were obtained from the mid-dorsal dentate gyrus within $\sim 300 \mu \mathrm{m}$ of the recording site. Arc mRNA and Arc protein staining was quantified using Nikon NIS-Elements AR software. Optical density was measured along the shortest line extending from the inner molecular layer to the hippocampal fissure and normalized to background staining in stratum radiatum of CA1. Measurements were obtained at three sites along the inner blade of the dentate gyrus and averaged. Ipsilateral values were then normalized to contralateral control. Phalloidin-FITC intensity was measured in $15 \mu \mathrm{m}$ steps across the molecular layer using NIH ImageJ software. Optical density values from 10 neighboring pixels were averaged and normalized relative to a reference area in CAl.

\section{Results}

\section{Dynamic role of Arc in LTP expression and consolidation}

Arc AS-ODN targeting the Arc start site (bases 209-228) was used to inhibit Arc synthesis during LTP induction at medial perforant path-granule cell synapses in anesthetized rats. To select optimal time points for AS delivery, we first examined expression of Arc mRNA and protein (Fig. 1). LTP was induced by spaced stimulation consisting of three sessions of HFS $(400 \mathrm{~Hz}$, eight pulses) with 5 min between sessions. LTP was associated with a rapid and sustained elevation of Arc mRNA and protein, as
A

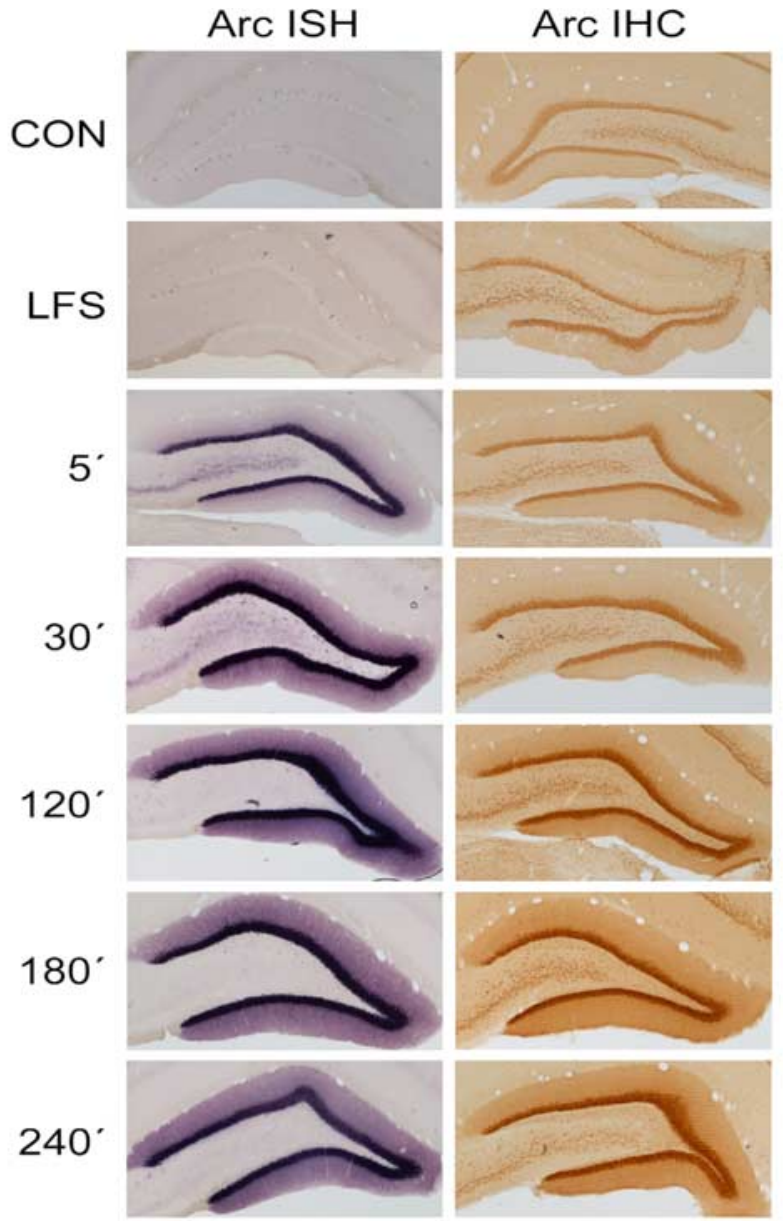

B

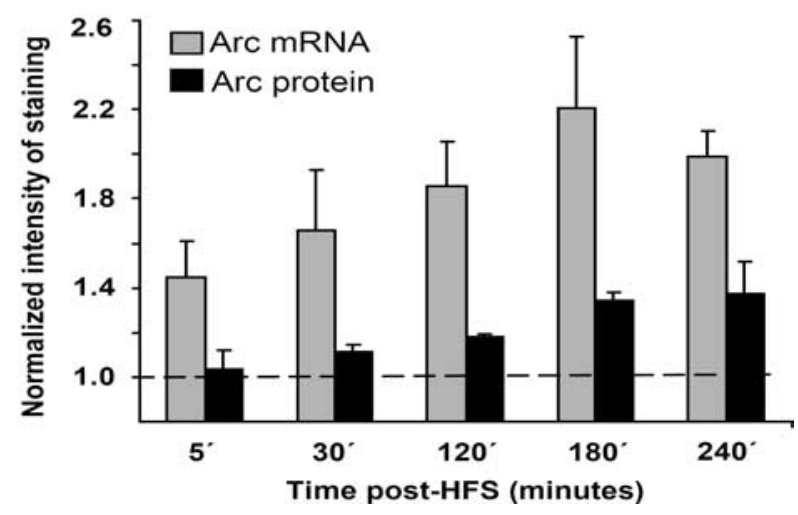

Figure 1. Time course of changes in Arc mRNA and protein expression after LTP induction in the dentate gyrus. Arc in situ hybridization (ISH) and immunohistochemistry (IHC) were performed at five time points after high-frequency stimulation of the medial perforant pathway. The high-frequency stimulation consisted of three sessions of $400 \mathrm{~Hz}$ bursts separated by $5 \mathrm{~min}$ (10 min total duration). Controls received no electrode implantation (CON) or electrode implantation and low-frequency test stimulation only (LFS). $A$, Representative images at each time point (in minutes after HFS). $n=4-5$ at each time point. $\boldsymbol{B}$, Quantitative analysis of staining in the dentate molecular layer. Optical density was measured in the molecular layer of the inner blade of the dentate gyrus. Changes in optical density on the ipsilateral LTP side are normalized to contralateral control values. Values are mean \pm SEM.

assessed by in situ hybridization histochemistry and immunohistochemistry performed at various time points $(5 \mathrm{~min}, 30 \mathrm{~min}, 2 \mathrm{~h}$, $3 \mathrm{~h}$, and $4 \mathrm{~h}$ ) after completing HFS (Fig. 1). Controls received low-frequency test pulse stimulation and were killed after baseline recording. At 5 and $30 \mathrm{~min}$ after HFS, Arc mRNA and protein 
staining were already increased in the granule cell layer and into the dendritic field (molecular layer) of the dentate gyrus. At $2 \mathrm{~h}$ after HFS, Arc mRNA and protein expression reached a plateau, where it remained at 3 and $4 \mathrm{~h}$, the intense staining filling the entire molecular layer. A similar pattern of enhanced Arc immunostaining was obtained with two antibodies recognizing different portions of the Arc protein (supplemental Fig. S1, available at www. jneurosci.org as supplemental material). When Arc was overexpressed in HEK293 cells, these antibodies recognized a bold single band that was absent in control cultures (supplemental Fig. S1, available at www.jneurosci.org as supplemental material).

Based on the large increases in Arc mRNA and protein at $2 \mathrm{~h}$ after HFS, we selected this time point for application of Arc AS. Infusions ( $1 \mu \mathrm{l}, 12.5 \mathrm{~min}$ ) were made into deep stratum lacunosummoleculare of CA1, $\sim 300 \mu \mathrm{m}$ from the nearest medial perforant path synapses in the upper blade of the dentate gyrus. As shown in Figure $2 \mathrm{~A}$, Arc AS applied $2 \mathrm{~h}$ after HFS led to a rapid and profound reversal of ongoing LTP. Potentiated fEPSPs declined to a stable baseline level within 60 min, where they remained for the duration of recording (at least $2 \mathrm{~h}$ ). In striking contrast, infusion of Arc AS $4 \mathrm{~h}$ after HFS (Fig. $2 B$ ) had no effect on LTP maintenance, demonstrating the time sensitivity of the AS effect. Infusion of control, SC Arc ODN at the critical $2 \mathrm{~h}$ time point was also without effect (Fig. 2C). In addition, Arc AS treatment in the absence of HFS had no effect on basal synaptic efficacy (Fig. 2D). Throughout this study, effects on the fEPSP slope were paralleled by similar changes in the amplitude of the population spike. To rule out possible spurious off-target effects of the AS sequence, we examined the effect of a second AS-ODN targeting a nonoverlapping 18 nucleotide sequence of the Arc coding region (bases 943-960). Infusion of this AS sequence $2 \mathrm{~h}$ after HFS similarly resulted in rapid inhibition of LTP (Fig. $2 E)$. These convergent physiological effects of AS treatment indicate inhibition of Arc synthesis as the mechanism of action.

The efficacy and specificity of the Arc protein knockdown was assessed by quantitative immunoblot analysis. Arc AS was infused $2 \mathrm{~h}$ after HFS, and homogenates of microdissected dentate gyrus were collected $2 \mathrm{~h}$ later. Arc protein expression in the AS-treated group was significantly reduced to $55 \pm 10 \%$ of SC-treated control (Fig. $2 G$ ). A panel of proteins was chosen to evaluate the specificity of the Arc knockdown. mRNA encoding $\alpha$-CaMKII is stored in dendrites, and local translation of this message affects the size of the PSD and development of late LTP (Miller et al., 2002; Havik et al., 2003). The scaffolding protein PSD-95 is part of the core PSD complex of exci-

C

G
B
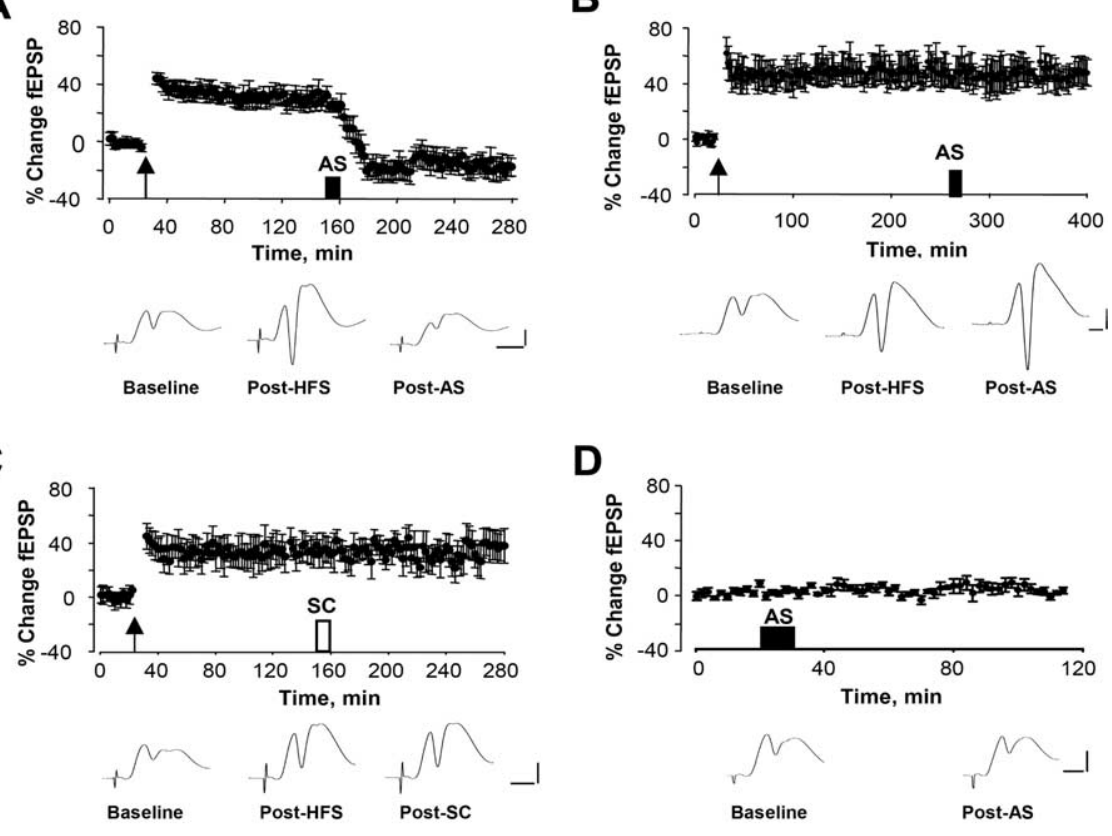

D

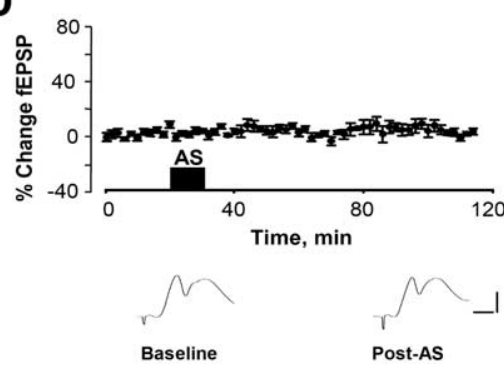

$\mathbf{F}$
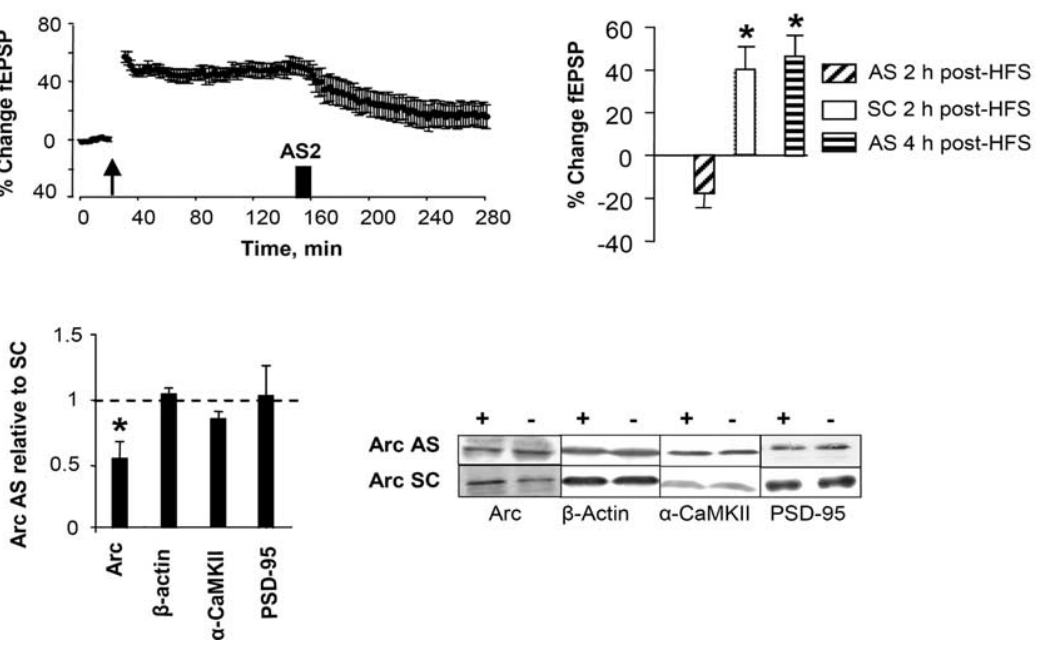

Figure 2. Arc antisense infusion $2 \mathrm{~h}$ after high-frequency stimulation blocks LTP consolidation. Time course plots show changes in the medial perforant path-evoked fEPSP slope expressed in percentage of baseline. Values are means \pm SEM. HFS is indicated by the arrow. Infusion of Arc AS- and SC-ODN are indicated by filled and open bars, respectively. A, Top, LTP maintenance was rapidly and persistently inhibited after local infusion ( $1 \mu \mathrm{l}, 0.5 \mathrm{~mm}, 12.5 \mathrm{~min})$ of Arc AS-ODN at $2 \mathrm{~h}$ after HFS. Bottom, Averaged field potentials traces (4 sweeps) collected at the end of baseline recording (Baseline), immediately before AS infusion (Post-HFS), and at the end of recording (Post-AS). Calibration: $5 \mathrm{mV}, 2 \mathrm{~ms}$. B, ArC AS-ODN infusion $4 \mathrm{~h}$ after HFS had no effect on LTP maintenance. C, Infusion of SC Arc ODN $2 \mathrm{~h}$ after HFS had no effect on LTP maintenance. D, Arc AS infusion had no effect on basal synaptic efficacy. $E$, Infusion of a second AS sequence (AS2) targeting a nonoverlapping region of the Arc mRNA similarly reversed ongoing LTP $(n=5)$. $\boldsymbol{F}$, Magnitude of fEPSP slope changes. $n=5-8$ in all groups. ${ }^{*} p<0.05$, significantly different from baseline. G, LTP reversal is coupled to specific knockdown of Arc protein. Quantification of Western blots from dentate gyrus homogenates. Tissue was collected at the end of the experiments shown in $A$ and $C$. Expression of Arc, but not $\beta$-actin, $\alpha$-CaMKII, or PSD-95, were significantly reduced in AS-treated rats ( $\left.{ }^{*} p<0.05\right)$. Representative immunoblots: + indicates infused dentate gyrus, and - indicates contralateral, non-infused dentate gyrus.

tatory synapses, in which it colocalizes with Arc and CaMKII (Lyford et al., 1995; Husi et al., 2000; Moga et al., 2004). $\beta$-Actin serves as a loading control but is also of interest because Arc cosediments with crude F-actin (Lyford et al., 1995). AS treatment $2 \mathrm{~h}$ after HFS had no effect on the expression of these proteins relative to SC-treated control (Fig. 2G). Thus, reversal of LTP by Arc AS is coupled to specific knockdown of Arc protein expression.

These results indicate that Arc synthesis at $2 \mathrm{~h}$ is critical for 
A

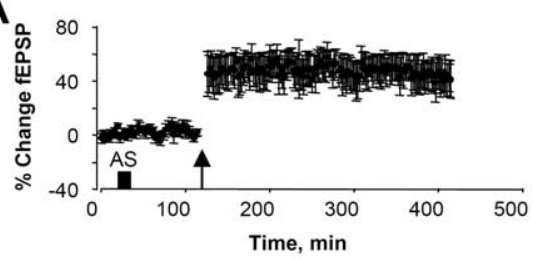

C

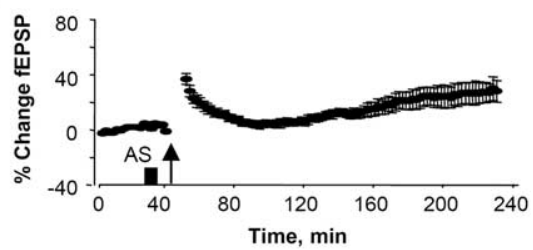

$\mathbf{E}$

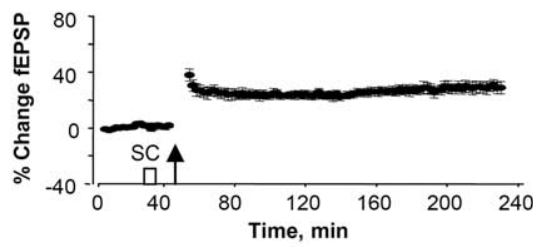

B

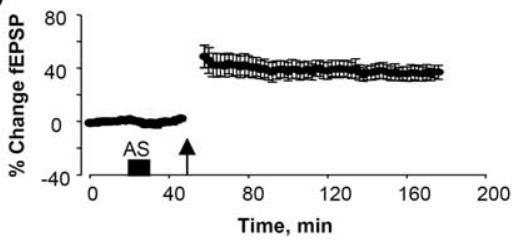

D
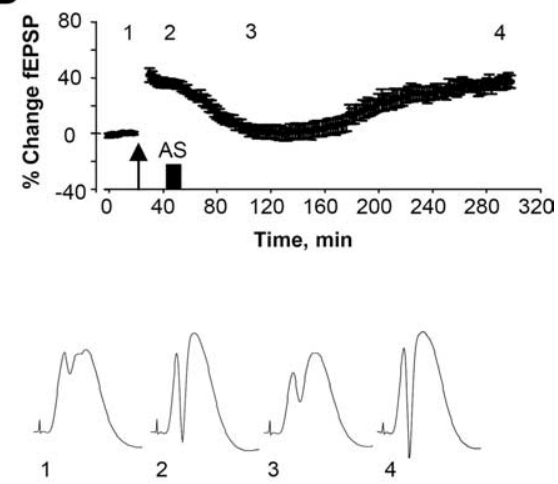

$\mathbf{F}$
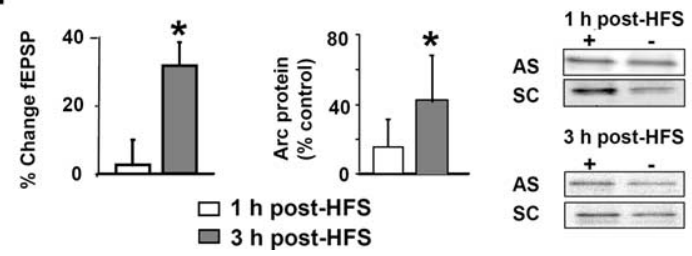

Figure 3. Arc antisense transiently inhibits early LTP expression. $A, B$, Nondecremental LTP of fEPSPs was induced when ArC AS was infused $90 \mathrm{~min}(\boldsymbol{A})$ or $15 \mathrm{~min}(\boldsymbol{B})$ before HFS. $\boldsymbol{C}, \boldsymbol{D}$, Infusion of Arc AS $5 \mathrm{~min}$ before HFS (C) or $15 \mathrm{~min}$ after HFS (D) resulted in transient suppression of LTP. D, Bottom, Averaged field potentials traces (4 sweeps) collected at the time points indicated in the LTP plot. $\boldsymbol{E}$, Nondecremental LTP was observed in SC-treated controls. $\boldsymbol{F}$, Bar graphs show changes in fEPSP and Arc protein expression in rats infused with Arc AS 5 min before HFS. Values for both were unchanged at $1 \mathrm{~h}$ (reversal) and significantly elevated at $3 \mathrm{~h}$ (recovery) after HFS $(p<0.05)$. fEPSP is expressed in percentage of baseline. Arc protein immunoreactivity on Western blots is expressed as percentage of contralateral control. $n=6-8$ in all groups. Representative Western blots are shown at right.

induction, and (3) late Arc synthesis is required for LTP consolidation.

LTP reversal is coupled to rapid knockdown of induced Arc mRNA and protein in dentate granule cells

In view of the critical role for late Arc synthesis in LTP consolidation, we focused our additional analysis on the $2 \mathrm{~h}$ time point after HFS. In situ hybridization and immunohistochemistry were performed to evaluate the cellular localization, mechanism, and speed of the Arc knockdown. Figure 4 shows changes in Arc mRNA and protein expression in experiments in which Arc AS- or SC-ODN was infused $2 \mathrm{~h}$ after HFS, and brains were collected $1 \mathrm{~h}$ later, at which time LTP was significantly inhibited in all rats. In SC-infused rats, HFS resulted in robust induction of Arc mRNA in the granule cell layer and throughout the molecular layer of the dentate gyrus. As shown in Figure $4 A$, the LTP-associated increase in Arc mRNA expression was strongly inhibited in timematched, AS-treated rats. The knockdown of newly induced Arc mRNA was observed in both blades of the dentate gyrus in all experiments (five of five). This rapid loss of mRNA staining indicated effective ASmediated degradation of newly induced, dendritically transported Arc transcripts. In contrast, expression of dendritically stored $\alpha$-CaMKII mRNA was unaffected by AS infusion (Fig. $4 B$ ). The effects of Arc AS on immunohistochemical staining of the Arc protein matched those of the Arc mRNA (Fig. 4C). Quantitative densitometric analysis showed a significant $49 \%$ reduction in Arc protein immunostaining

LTP consolidation. Next we sought to determine the onset and possible early contribution of Arc synthesis to LTP. When Arc AS was applied 90 or 15 min before HFS, nondecremental LTP of fEPSPs was obtained (Fig. $3 A, B$ ). The lack of effect of AS infusion at these time points suggested that the concentration of AS-ODN dropped below a critical level needed to target the massive increase in Arc mRNA after HFS. Corroborating this, LTP was rapidly inhibited when AS was applied 5 min before HFS (Fig. 3C). fEPSP slope values started to decline within 5 min after HFS and reached a maximum trough at $\sim 1 \mathrm{~h}$. Surprisingly, however, the response returned to the original level of enhancement by $3 \mathrm{~h}$ after HFS (Fig. 3C,F). The same pattern of transient inhibition of LTP was observed when AS was given 15 min after HFS, showing that the effect is not attributable to perturbation of LTP induction (Fig. 3D). Rats receiving SC-ODN 5 min before HFS had nondecremental LTP, and the size of the fEPSP increase recorded immediately after HFS and $3 \mathrm{~h}$ after HFS was not significant differently from the AS group (Fig. $3 E)(p>0.05)$. Finally, inhibition and recovery of LTP expression was paralleled by inhibition and recovery of enhanced Arc protein expression (Fig. $3 F$ ). Together, these results suggest that (1) early Arc synthesis is necessary for early LTP expression but not LTP consolidation, (2) Arc synthesis critical to LTP is sustained, lasting between 2 and $4 \mathrm{~h}$ after LTP in the dentate molecular layer of AS-treated rats relative to the SC-treated control group. Thus, AS-induced reversal of LTP is associated with rapid inhibition of Arc synthesis from newly induced, dendritically transported Arc mRNA.

\section{Late Arc synthesis is required for stabilization of F-actin during LTP}

Recent work suggests that development of stable LTP involves actin polymerization-dependent remodeling of dendritic spines (Fukazawa et al., 2003; Matsuzaki et al., 2004; Zito et al., 2004). We examined a role for late Arc synthesis in this process using fluorescently labeled phalloidin to visualize changes in F-actin content. In agreement with Fukazawa et al. (2003), LTP was accompanied by enhanced phalloidin staining within a narrow band corresponding to the termination zone of medial perforant path synapses in the middle molecular layer of the dentate gyrus (Fig. 5A). This band of phalloidin staining appeared within $5 \mathrm{~min}$ of HFS and remained constant during $4 \mathrm{~h}$ of recording (time course shown in supplemental Fig. S2, available at www. jneurosci.org as supplemental material). Rats receiving SC infusions $2 \mathrm{~h}$ after HFS exhibited a clear band of phalloidin staining that was absent in time-matched AS-treated rats (Fig. 5A, bottom right panels). Densitometric analysis of the staining confirmed a 
A

Arc mRNA
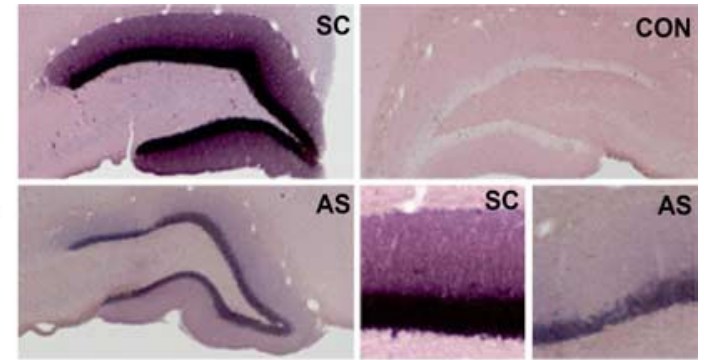

B
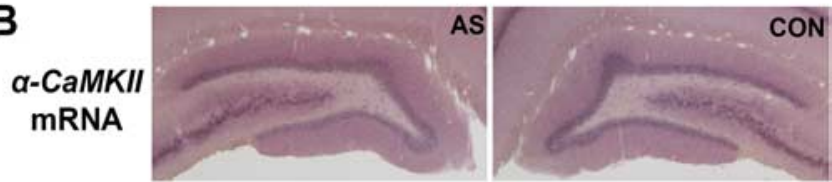

C

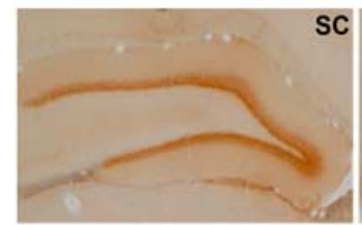

C

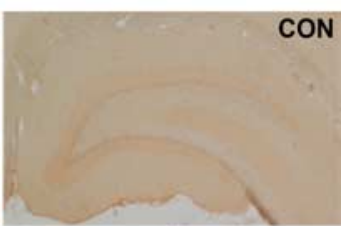

Arc

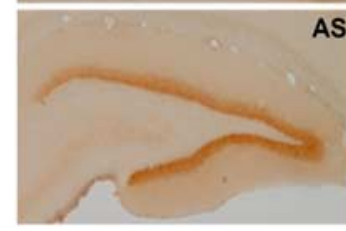

AS

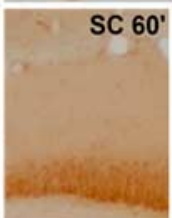

AS $60^{\prime}$

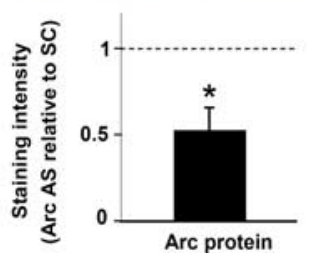

$\operatorname{sc~} 30^{\circ}$

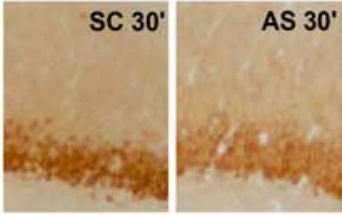

Figure 4. LTP reversal is coupled to rapid knockdown of upregulated Arc mRNA and protein expression. Arc AS- or SC-ODN was infused $2 \mathrm{~h}$ after LTP induction, and the brain was fixed by transcardial perfusion $1 \mathrm{~h}$ later. $\boldsymbol{A}$, Coronal sections processed for in situ hybridization using a digoxigenin-labeled Arc riboprobe show robust upregulation of Arc mRNA in granule cell somata and dendrites in SC-treated controls. Arc mRNA expression was strongly inhibited after Arc AS treatment. The bottom right panels show high-magnification images of AS-treated and SC-treated dentate gyrus. CON, Contralateral nontreated dentate gyrus. These are representative images based on five experiments in each treatment group. Images were obtained from the mid-dorsal dentate gyrus within $\sim 300 \mu \mathrm{m}$ of the recording site. $\boldsymbol{B}, \alpha$-CaMKII mRNA expression in Arc AS-treated and contralateral dentate gyrus. C, Arc immunohistochemical staining. Arc expression in dentate molecular and granule cell layer was reduced in AS-treated rats relative to time-matched, SC-treated control. High-magnification images of Arc staining at 60 and 30 min after AS or SC infusion at $2 \mathrm{~h}$ after HFS are shown in the bottom right panels. The bar graph shows the quantitative analysis of immunohistochemical staining in the dentate molecular layer at the $1 \mathrm{~h}$ time point. Optical density measurements were obtained along a line extending across the molecular layer of the inner blade of the dentate gyrus and normalized to background staining in stratum radiatum of CA1. Changes in Arc protein expression after AS treatment are normalized to SC-treated control. ${ }^{*} p<0.05$.

peak corresponding to the middle molecular layer in SC-treated controls that was lacking in AS-treated animals (Fig. 5B). This suggested that late Arc synthesis is necessary for consolidation of LTP and stabilization of F-actin at synaptic sites. Finally, we found that longer sessions of HFS $(400 \mathrm{~Hz}$, eight-pulse bursts given every $10 \mathrm{~s}$ for $2 \mathrm{~h} ; 7680$ stimulus pulses total) produce a qualitatively similar but more intense phalloidin band (Fig. 5C). This is noteworthy because such stimulation protocols are effective in localizing Arc mRNA to activated synapses (Steward and Worley, 2001b).

Next we asked whether F-actin stabilization mediates Arc-
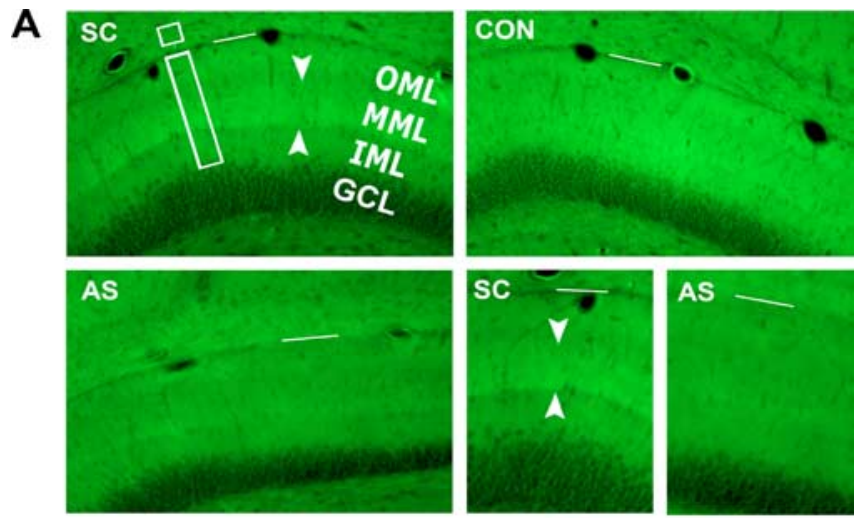

B

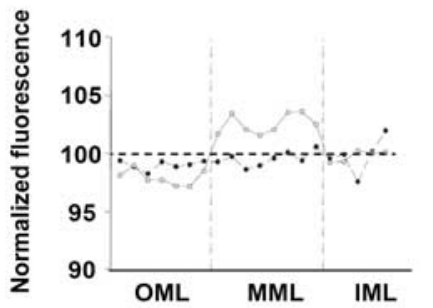

D

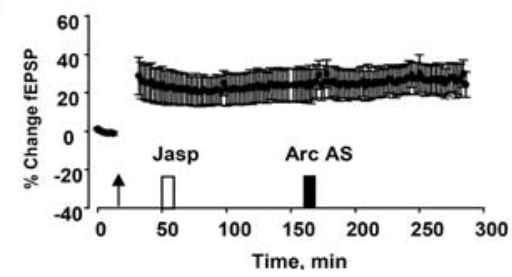

Figure 5. Late Arc synthesis is required to stabilize F-actin during LTP. ArC AS- or SC-ODN was locally infused $2 \mathrm{~h}$ after HFS, and the brain was fixed by transcardial perfusion $1 \mathrm{~h}$ later. Coronal sections were stained with phalloidin-FITC. $A$, Top left, A band of phalloidin staining specific to the termination zone of the medial perforant path was observed in the dentate gyrus of SCtreated rats. Top right, Contralateral, unstimulated dentate gyrus (CON). Bottom left, Arc AS treatment abolished the band of enhanced phalloidin staining. Bottom right, Comparison of phalloidin staining in SC- and AS-treated rats. OML, Outer molecular layer; $\mathrm{MML}$, middle molecular layer; IML, inner molecular layer; GCL, granule cell layer. Arrowheads mark phalloidin staining in the middle molecular layer. The white bar marks the hippocampal fissure. Representative images based on four AS-treated and five SC-treated rats. The time course of phalloidin labeling is shown in supplemental Figure 1 (available at www.jneurosci.org as supplemental material). B, Profile of phalloidin-FITC fluorescence intensity ratio (ipsilateral/contralateral) in rats receiving SC (gray) or AS (black) infusion. Fluorescence intensity of the phalloidin-FITC signal was measured in $15 \mu \mathrm{m}$ steps along the shortest line (rectangle in $\boldsymbol{A}$ ) extending from 20 $\mu \mathrm{m}$ above the granule cell layer border to the hippocampal fissure. Optical density values from 10 neighboring pixels were averaged. Florescence values at each pixel were normalized relative to a reference area in $C A 1$ (small box in $A$ ). Values obtained at three sites along the dentate gyrus inner blade were averaged, and group means were obtained. All sections were from within 300 $\mu \mathrm{m}$ of the recording site. C, Phalloidin staining after $2 \mathrm{~h}$ of $400 \mathrm{~Hz}$, eight-pulse bursts applied at 10 s intervals. A bright, sharply demarcated band appears in the middle molecular layer of the dentate gyrus. $\boldsymbol{D}$, Infusion of the F-actin stabilizing agent jasplakinolide blocks the inhibitory effect of Arc AS on LTP maintenance. Jasplakinolide (Jasp; $1 \mu \mathrm{m}$ ) and Arc AS were infused at the times indicated after HFS. Pretreatment with jasplakinolide did not affect ongoing LTP and abolished the effect of Arc AS on LTP maintenance. fEPSP slope measurements of six consecutive responses obtained immediately before and $10 \mathrm{~min}$ after jasplakinolide or Arc infusion were not significantly different $(p<0.05)$.

dependent consolidation. If so, drug-induced stabilization of F-actin during LTP maintenance should occlude (block) the effect of Arc AS treatment. Figure 5D shows the results of experiments in which the F-actin stabilizer jasplakinolide was briefly infused during LTP maintenance $1 \mathrm{~h}$ before Arc AS treatment. Remarkably, jasplakinolide had no effect on LTP maintenance yet completely abolished the ability of AS to reverse LTP. Jas- 


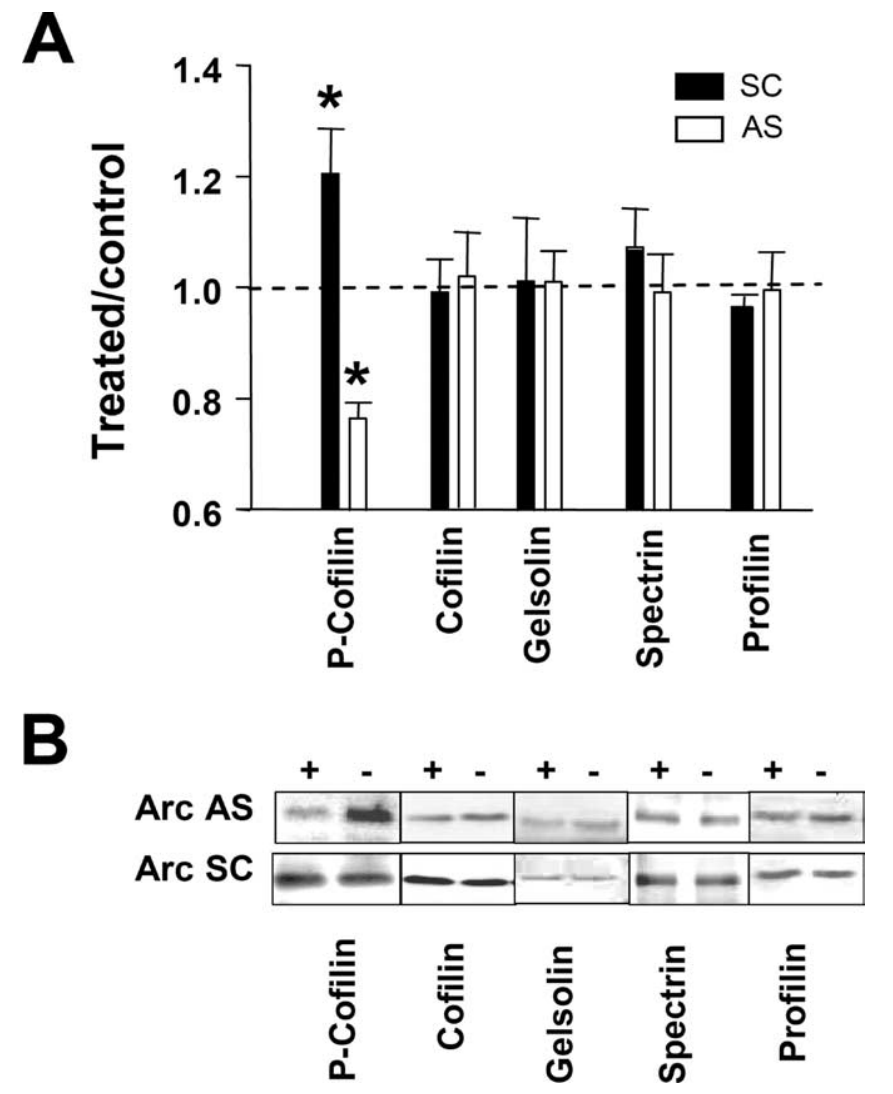

Figure 6. Arc synthesis is necessary to maintain hyperphosphorylation of cofilin during LTP. $\boldsymbol{A}$, Western blots were performed in dentate gyrus homogenates prepared $2 \mathrm{~h}$ after HFS and $2 \mathrm{~h}$ after infusion of AS or SC Arc ODN during LTP. Cofilin phosphorylation was significantly enhanced during LTP, and this increase was inhibited by Arc AS treatment ${ }^{*} p<0.05 ; n=6-7$ in all groups). Expression of total cofilin and other actin-associated proteins was unchanged. $\boldsymbol{B}$, Representative immunoblots. + indicates ODN-infused dentate gyrus; - indicates contralateral, non-infused dentate gyrus.

plakinolide also had no effect on LTP maintenance during a $2.5 \mathrm{~h}$ recording period in the absence of AS application (data not shown).

\section{Arc synthesis maintains cofilin phosphorylation during LTP}

Next we began to explore mechanisms that may couple Arc synthesis to regulation of F-actin. Cofilin is a member of a highly conserved family of actin-associated proteins that enhance actin filament severing and increase the off rate of actin monomers (Sarmiere and Bamburg, 2004). Phosphorylation of cofilin on Ser-3 inhibits cofilin activity and promotes F-actin formation. Previous work showed that cofilin phosphorylation is critical for F-actin formation underlying late LTP (Fukazawa et al., 2003). Here, we examined the role of ongoing Arc synthesis in the regulation of cofilin activity. LTP was associated with marked hyperphosphorylation of cofilin, whereas infusion of Arc AS $2 \mathrm{~h}$ after LTP induction resulted in rapid dephosphorylation of cofilin (Fig. 6A, $B$ ). Expression of total cofilin and other actin-binding proteins connected to actin function in spines, including gelsolin, $\alpha$-spectrin, and profilin, did not change significantly after LTP induction or AS-induced reversal of LTP (Fig. 6B).

\section{BDNF triggers Arc-dependent synaptic consolidation}

BDNF has emerged as major regulator of excitatory synaptic transmission and plasticity in the CNS (Blum and Konnerth, 2005; Bramham and Messaoudi, 2005). Development of transcription-dependent late-phase LTP after spaced HFS requires activation of TrkB receptor tyrosine kinase and is associated with a period of sustained BDNF release (Kang et al., 1997; Aicardi et al., 2004). However, the molecular effector mechanisms by which BDNF regulates LTP consolidation are unknown. Exogenous application of BDNF induces a long-term potentiation (BDNF-LTP) that mimics many features of late-phase LTP. In the dentate gyrus, BDNF is transcription-dependent and associated with induction, dendritic transport, and translation of Arc mRNA (Messaoudi et al., 2002; Ying et al., 2002). Here, we used Arc antisense infusion to explore a possible role for Arc in BDNF-LTP.

Rats infused with scrambled Arc ODN before BDNF infusion exhibited a stable fEPSP increase equivalent in magnitude to that seen in rats receiving BDNF alone (Fig. 7A). Pretreatment with Arc AS completely blocked BDNF-LTP induction but had no effect on baseline synaptic efficacy (Fig. 7B). Inhibitors of RNA synthesis or extracellular signal-regulated kinase (ERK) block BDNF-LTP induction but have no effect when applied during the maintenance phase of the potentiation (Messaoudi et al., 2002; Ying et al., 2002) In striking contrast, application of Arc AS $2 \mathrm{~h}$ after completing BDNF infusion led to a rapid reversal of ongoing BDNF-LTP (Fig. 7C). As seen during HFS-LTP maintenance, fEPSP slope values returned completely to baseline levels within $1 \mathrm{~h}$ of AS treatment and remained at baseline for the duration of recording. Local infusion of scrambled Arc ODN $2 \mathrm{~h}$ after BDNF infusion (Fig. 7D) or treatment with Arc AS $4 \mathrm{~h}$ after BDNF infusion (Fig. 7E) had no effect on the magnitude of potentiation during $2 \mathrm{~h}$ of subsequent recording. The effects of Arc AS on BDNF-LTP are summarized in Figure $7 F$.

The blockade of BDNF-LTP induction was associated with specific knockdown of Arc expression on immunoblots (Fig. 7G). Arc protein expression and cofilin phosphorylation were then examined in tissue obtained after reversal of BDNF-LTP by Arc AS infusion. Arc AS treatment $2 \mathrm{~h}$ after BDNF infusion significantly reduced Arc expression and phospho-cofilin levels relative to SC-treated control (Fig. 7H). Expression of cofilin (Fig. $7 \mathrm{H}$ ) and other actin binding proteins (gelsolin, $\alpha$-spectrin, and profilin), was unchanged. The results suggest that Arc synthesis is required for both the induction and time-dependent consolidation of BDNF-LTP.

Broad-spectrum protein synthesis inhibitors have been used to define the traditional phases of LTP. However, dynamic functions of individual mRNA species may not conform to these phases. First, it is well known the protein synthesis inhibitors have deleterious effects on cellular metabolism and homeostasis (Klann and Dever, 2004; Routtenberg and Rekart, 2005). Second, several studies of synaptic plasticity report maintained or enhanced synthesis of dendritically localized mRNAs [Arc, $\alpha$-CaMKII, and EF1A (elongation factor 1A)] in the presence of protein synthesis inhibitors (Hughes et al., 1997; Steward and Halpain, 1999; Huang et al., 2005) or during global translation arrest (Scheetz et al., 2000; Chotiner et al., 2003). In general, treatment with protein synthesis inhibitors before HFS cause a slowing decaying LTP, whereas treatment during LTP maintenance has no effect. We replicated these effects on LTP in the dentate gyrus using systemic and local injection of the protein synthesis inhibitors cycloheximide and anisomycin (supplemental Fig. S3, available at www.jneurosci.org as supplemental material). In contrast to the sharp reversal of LTP obtained after ASmediated inhibition of Arc synthesis, systemic and local administration of protein synthesis inhibitors at several time points during the Arc window failed to inhibit LTP maintenance, 
and anisomycin injected $30 \mathrm{~min}$ after HFS failed to block the increase in Arc protein expression.

\section{Discussion}

This study demonstrates a dynamic, stringent requirement for activity-induced Arc synthesis in LTP maintenance in the dentate gyrus in vivo. Arc synthesis is sustained during a critical window that lasts between 2 and $4 \mathrm{~h}$. Surprisingly, early Arc synthesis is necessary for expression of LTP, whereas late synthesis is required for LTP consolidation.

As part of a previous study in freely moving rats, Guzowski et al. (2000) reported that intrahippocampal injection of Arc AS before HFS led to a moderately faster decay of LTP over a period of $1-5 \mathrm{~d}$ after HFS. This contrasts with the robust, rapid function of Arc reported here. The discrepancy may reflect differences in the preparations used (freely moving vs anesthetized rat) or infusion paradigms. However, the effect of AS in the previous study is difficult to assess in the absence of data from baseline electrophysiological recordings before HFS. In the present study, we sought to resolve the dynamic function of Arc during LTP, and the specificity and validity of AS effects were corroborated in several ways. First, the effects of Arc AS were strikingly dependent on the timing of AS application during ongoing LTP. Thus, infusion of Arc AS $2 \mathrm{~h}$ after LTP induction or BDNF infusion completely reversed the increase in synaptic strength, whereas infusion at $4 \mathrm{~h}$ had no effect. Second, similar reversal of LTP was obtained with a second Arc AS targeting a nonoverlapping region of the Arc coding sequence, arguing against off target or spurious sequencespecific effects of the AS. Third, scrambled Arc ODN had no effect on LTP, and Arc AS did not alter basal synaptic efficacy. Fourth, LTP reversal was coupled to rapid and specific knockdown of Arc mRNA and protein in the dentate molecular layer as assessed by in situ hybridization, quantitative immunohistochemistry, and Western blotting. Finally, Arc synthesis was coupled to a biologically compelling mechanism-regulation of F-actin.

Evidence indicates that persistent LTP occurs when small stubby dendritic spines are converted into large mushroom-shaped spines through a mechanism dependent on local actin polymerization (Weeks et al., 2001; Fukazawa et al., 2003; Harris et al., 2003; Matsuzaki et al., 2004). Expansion of the PSD and spine head may depend on a number of F-actin functions, including tethering of receptors and signaling complexes, trafficking of receptors, positioning of polyribosomes, and modulation of translation factor activity (Kim and Lisman, 1999; Halpain, 2000; Zhou et al., 2001; Matsuzaki et al., 2004; Zito et al., 2004; Carlisle and Kennedy, 2005; Bramham and Wells, 2007). Fukazawa et al. (2003) showed that LTP at medial perforant
A

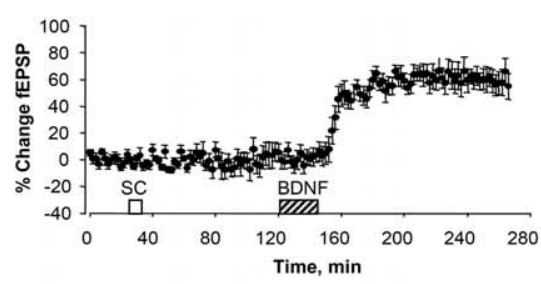

G

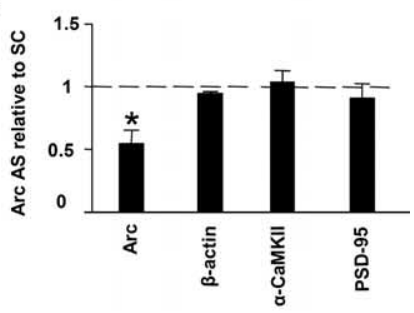

B
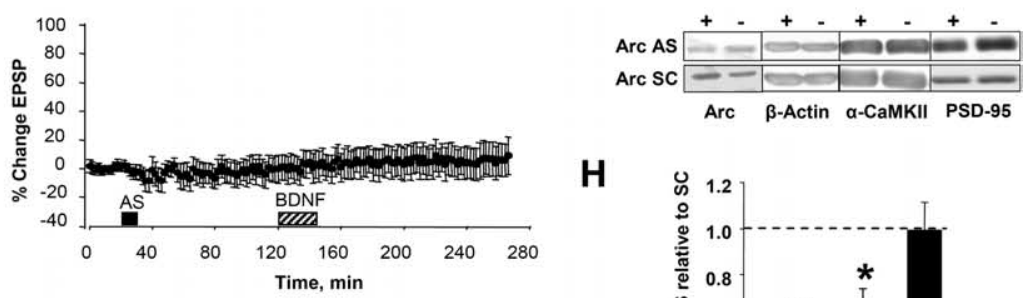

H
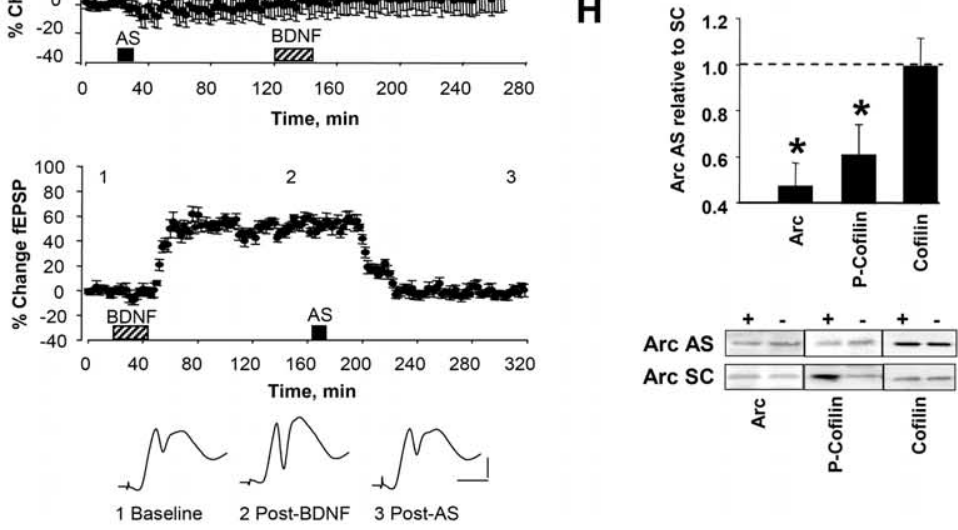

D

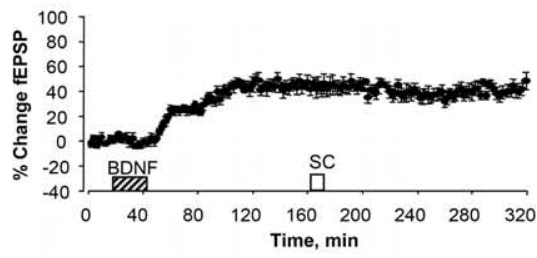

E

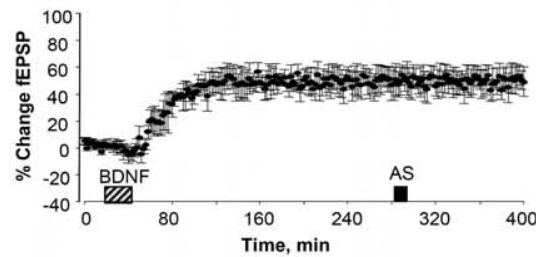

F

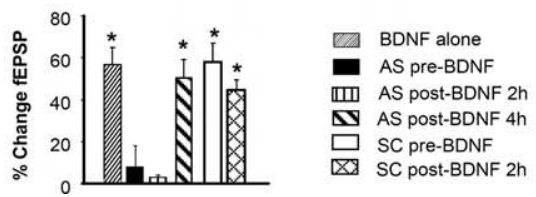

Figure 7. Arc AS blocked the induction and consolidation of BDNF-induced LTP. Time course plots show changes (means \pm SEM) in the medial perforant path-evoked fEPSP slope expressed in percentage of baseline. Arc AS oligodeoxynucleotide or SC Arc sequence were infused 90 min before BDNF. A, Robust BDNF-LTP was induced in SC-treated rats $(n=5 ; p<0.05)$. B, Arc AS pretreatment abolished BDNF-LTP $(n=6 ; p>0.05)$. There was no significant difference in fEPSP slope values obtained immediately before and $2 \mathrm{~h}$ after BDNF infusion ( $p>0.05$ ). C, Top, Arc AS infusion at $2 \mathrm{~h}$ rapidly reverses ongoing BDNF-LTP $(n=5$; $p<0.05$ ). Bottom, Averaged field potential traces (4 sweeps) collected at the times indicated (1. baseline; 2 , after BDNF; 3, after AS). Calibration: $2 \mathrm{mV}, 2 \mathrm{~ms}$. D, Infusion of SC Arc ODN at $2 \mathrm{~h}$ has no significant effect on ongoing BDNF-LTP $(n=5 ; p>0.05)$. $\boldsymbol{E}$, Arc AS infusion at $4 \mathrm{~h}$ had no significant effect on BDNF-LTP maintenance $(n=6 ; p>0.05)$. $\boldsymbol{F}$, Magnitude of fEPSP slope and population spike changes. $n=5-7$ in all groups. ${ }^{*} p<0.05$. G, Quantification of Western blots from dentate gyrus homogenates. Tissue was collected at the end of the experiments shown in $A$ and $B$. Expression of Arc, butnot $\beta$-actin, $\alpha$-CaMKII, or PSD-95, were significantly reduced in AS-treated rats ( $\left.{ }^{*} p<0.05\right)$. Representative immunoblots below. + indicates infused dentate gyrus; indicates contralateral, non-infused dentate gyrus. $\boldsymbol{H}$, Dentate gyrus was microdissected at the end experiments shown in $\mathbf{C}$ and $\boldsymbol{D}$, and homogenate samples were analyzed by quantitative Western blot. Mean \pm SEM changes are expressed as AS-treated versus SC-treated dentate gyrus $\left({ }^{*} p<0.05 ; n=6-7\right.$ in all groups). Representativeimmunoblots are shown below. + indicates infused dentate gyrus; - indicates contralateral, non-infused dentate gyrus. 
path synapses in vivo is associated with elevations in synaptic F-actin lasting at least 5 weeks. Our analysis of Arc function concentrated on the consolidation mechanism $2 \mathrm{~h}$ after LTP induction, at which time Arc AS infusion stably reversed LTP and knocked down newly induced Arc mRNA and protein. Infusion of AS induced dephosphorylation of hyperphosphorylated cofilin but abolished the nascent band of F-actin at medial perforant path synapses. Furthermore, infusion of the F-actin-stabilizing drug jasplakinolide blocked the Arc AS-induced reversal of LTP. Together, these findings indicate that Arc synthesis promotes LTP consolidation through local stabilization of F-actin. Arc thus appears to link two core requirements of LTP consolidation: gene expression and local actin polymerization.

The present data supports a role for sustained synthesis of rapidly degraded Arc in LTP consolidation. First, early inhibition of Arc synthesis blocks early but not late expression of LTP, whereas late inhibition of Arc synthesis abolishes persistent LTP. Second, rapid LTP reversal and recovery (in the case of early AS application) is paralleled by inhibition and recovery of Arc expression. Although the dynamics of Arc turnover remains to be directly studied, rapid turnover of Arc (on the order of minutes to hours) has been reported in several in vitro studies (Yin et al., 2002; Rao et al., 2006). Interestingly, two recent studies showed that drugs that block proteosome-dependent degradation of proteins, such as protein synthesis inhibitors, prevent formation of stable LTP (Fonseca et al., 2006; Karpova et al., 2006). This surprising observation suggested that stable LTP involves simultaneous rapid synthesis and degradation of proteins. One possibility is that the function of newly synthesized proteins, such as Arc, depends on their rapid degradation and replenishment.

Recent evidence suggests that late LTP expression is mediated by sustained activation of the atypical PKC isoform PKM $\zeta$ (Ling et al., 2006). In the dentate gyrus, pharmacological inhibition of $\mathrm{PKM} \zeta$ reverses LTP $1 \mathrm{~d}$ after its induction (Pastalkova et al., 2006). Interestingly, treatment with the F-actin destabilizing agent latrunculin B blocks new synthesis of PKM $\zeta$ (which occurs at least partly in dendrites) and attenuates LTP maintenance (Kelly et al., 2007). Together, this raises the tantalizing possibility of a sequential mechanism of LTP maintenance in which Arcdependent stabilization of F-actin promotes PKM $\zeta$ synthesis and expression of enduring LTP.

The mechanism coupling Arc synthesis to phosphorylation of cofilin is unknown. Arc and cofilin are both PSD proteins. Arc also coimmunoprecipitates with PSD-95, cosediments with crude (but not pure) F-actin, and contains spectrin homology repeats suggestive of a structural role (Lyford et al., 1995; Husi et al., 2000; Donai et al., 2003). Phosphorylation of cofilin on serine 3 is regulated by multiple kinases and phosphatases (Arber et al., 1998; Yang et al., 1998; Meng et al., 2002). One of the major cofilin kinases in neurons, Lim domain kinase (LIMK), is regulated by the Rho GTPase effectors Rho kinase (ROCK) and p21activated kinase (PAK). Experiments showing normal LTP maintenance in the presence of ROCK inhibitors (A. Tiron and C. R. Bramham, unpublished observations) places emphasis on PAK, which both activates LIMK1 and inhibits activity of the cofilin phosphatase slingshot (Sarmiere and Bamburg, 2004). Furthermore, recent work shows that PAK and cofilin are phosphorylated in dendritic spines in response to LTP-inducing stimulation and application of BDNF (Chen et al., 2007; Rex et al., 2007).

In Arc knock-out mice, LTP is initially enhanced and then falls quickly to baseline (Plath et al., 2006). The loss of stable LTP resembles the effect of Arc antisense, whereas the superinduction of LTP resembles observations in LIMK1 knock-out mice, which exhibit large numbers of small, actin-poor spines. Given the role of Arc in regulation of actin polymerization, we predict that Arc knock-outs also have small spines that cannot undergo actindependent enlargement.

Recent studies performed in dissociated hippocampal neurons and slice cultures have demonstrated a role for Arc in homeostatic synaptic scaling of AMPA-type glutamate receptor (AMPAR) transmission via its ability to activate a specific AMPAR endocytic pathway (Rial Verde et al., 2006; Chowdhury et al., 2006; Shepherd et al., 2006). The endocytosis of AMPARs and depression of excitatory transmission observed after Arc overexpression in vitro appears to be at odds with the present findings based on acute inhibition of endogenous Arc synthesis during in vivo LTP. Although electron microscopic analysis has revealed transient upregulation of Arc specific to spines of medial perforant path synapses during LTP (Moga et al., 2004; Rodriguez et al., 2005), it is evident from many studies that Arc protein is upregulated throughout the dendritic arbor of adult granule cells. Attempting to reconcile the datasets, it is conceivable that distinct pools of Arc have distinct functions such that Arc-dependent LTP consolidation in recently activated spines is followed by a dendrite-wide homeostatic scaling that resets the excitability of synaptic inputs. It seems clear that Arc plays multiple roles in synaptic regulation.

LTP maintenance has been divided previously into early and late phases based on the effects of general protein synthesis inhibitors. Because such inhibitors perturb cell metabolism and have variable effects on the translation of some dendritic mRNAs (Wallace et al., 1998; Steward and Halpain, 1999; Huang et al., 2005; Routtenberg and Rekart, 2005), their actions may not accurately reflect the contribution of activity-induced protein synthesis to LTP. By specifically targeting Arc synthesis, we revealed a novel dynamic in LTP maintenance of the dentate gyrus.

Endogenous BDNF signaling at glutamate synapses is critical for formation of late-phase LTP (Bramham and Messaoudi, 2005), but the molecular mechanisms have not been resolved. Exogenous BDNF-induced LTP provides a means to dissect these mechanisms. BDNF-LTP in the dentate gyrus is transcription dependent, it occludes with late LTP, and it is associated with ERK-dependent upregulation of Arc. In the present study, we show that BDNF-LTP is completely abolished by Arc AS treatment before BDNF infusion and rapidly reversed by AS treatment at $2 \mathrm{~h}$ (but not $4 \mathrm{~h}$ ) after BDNF infusion. As with HFS-LTP, Arc AS treatment selectively inhibited Arc expression and suppressed phosphorylation of cofilin. Thus, the induction and time-dependent consolidation of BDNF-LTP requires Arc synthesis.

Rather than acting alone, Arc is likely to be part of a coordinated transcriptional and translational response. A panel of genes that are co-upregulated with Arc during BDNF-LTP and HFSLTP was recently identified (Wibrand et al., 2006). Several of these genes [Narp (neuronal activity regulated pentraxin), neuritin, Nedd4 WW-binding protein-4) have functions in AMPAR clustering, excitatory synaptogenesis, and axonal guidance. BDNF signaling also modulates the dendritic translation of Arc, $\alpha$-CaMKII, LIMK1, and other plasticity-associated mRNAs (Aakalu et al., 2001; Yin et al., 2002; Ju et al., 2004; Schratt et al., 2004). Although light microscopic in situ hybridization shows Arc mRNA in proximal dendrites within 5 min of HFS (15 min from first session of HFS), the possible contribution of preexisting Arc mRNA in early LTP expression warrants attention. Arc and $\alpha$-CaMKII mRNA are co-stored in Pur- $\alpha$ (purine-rich element binding protein $\alpha$ ) containing RNA transport granules in 
dendrites (Kanai et al., 2004), and BDNF stimulates synthesis of both proteins in isolated synaptic preparations derived from adult rats (Yin et al., 2002; Kanhema et al., 2006).

Arc is expressed in many cortical and limbic structures during behavioral training and is necessary for long-term memory in a variety of hippocampus-dependent and hippocampusindependent memory tasks (Guzowski et al., 1999, 2000; Plath et al., 2006). Arc mRNA levels are elevated for hours after LTP induction or exploration of a novel environment, whereas Arc mRNA increases in the hippocampal region CA1 and many other brain areas are only short-lived (minutes) (Kelly and Deadwyler, 2003; Ramirez-Amaya et al., 2005; Guzowski et al., 2006). Recent work suggests that the dentate gyrus allows fine spatiotemporal separation of novel and complex cues, thereby disambiguating stimuli to allow sparse encoding of information (Kesner et al., 2004; Lee et al., 2005; McHugh et al., 2007). It will be important to determine whether the protracted time window of LTP consolidation in the dentate gyrus reflects the unique functions of this structure.

\section{References}

Aakalu G, Smith WB, Nguyen N, Jiang C, Schuman EM (2001) Dynamic visualization of local protein synthesis in hippocampal neurons. Neuron 30:489-502.

Aicardi G, Argilli E, Cappello S, Santi S, Riccio M, Thoenen H, Canossa M (2004) Induction of long-term potentiation and depression is reflected by corresponding changes in secretion of endogenous brain-derived neurotrophic factor. Proc Natl Acad Sci USA 101:15788-15792.

Arber S, Barbayannis FA, Hanser H, Schneider C, Stanyon CA, Bernard O, Caroni P (1998) Regulation of actin dynamics through phosphorylation of cofilin by LIM-kinase. Nature 393:805-809.

Bliss T, Collingridge G, Morris R (2007) Synaptic plasticity in the hippocampus. In: The hippocampus book (Andersen P, Morris R, Amaral D, Bliss T, O'Keefe J, eds), pp 343-474. Oxford: Oxford UP.

Blum R, Konnerth A (2005) Neurotrophin-mediated rapid signaling in the central nervous system: mechanisms and functions. Physiology (Bethesda) 20:70-78.

Bramham CR, Messaoudi E (2005) BDNF function in adult synaptic plasticity: the synaptic consolidation hypothesis. Prog Neurobiol 76:99-125.

Bramham CR, Wells DG (2007) Dendritic mRNA: transport, translation, and function. Nat Rev Neurosci 8:776-789.

Carlisle HJ, Kennedy MB (2005) Spine architecture and synaptic plasticity. Trends Neurosci 28:182-187.

Chen LY, Rex CS, Casale MS, Gall CM, Lynch G (2007) Changes in synaptic morphology accompany actin signaling during LTP. J Neurosci 27:5363-5372.

Chotiner JK, Khorasani H, Nairn AC, O’Dell TJ, Watson JB (2003) Adenylyl cyclase-dependent form of chemical long-term potentiation triggers translational regulation at the elongation step. Neuroscience 116:743-752.

Chowdhury S, Shepherd JD, Okuno H, Lyford G, Petralia RS, Plath N, Kuhl D, Huganir RL, Worley PF (2006) Arc/Arg3.1 interacts with the endocytic machinery to regulate AMPA receptor trafficking. Neuron 52:445-459.

Donai H, Sugiura H, Ara D, Yoshimura Y, Yamagata K, Yamauchi T (2003) Interaction of Arc with CaM kinase II and stimulation of neurite extension by Arc in neuroblastoma cells expressing CaM kinase II. Neurosci Res 47:399-408.

Fonseca R, Vabulas RM, Hartl FU, Bonhoeffer T, Nagerl UV (2006) A balance of protein synthesis and proteasome-dependent degradation determines the maintenance of LTP. Neuron 52:239-245.

Frey U, Frey S, Schollmeier F, Krug M (1996) Influence of actinomycin D, a RNA synthesis inhibitor, on long- term potentiation in rat hippocampal neurons in vivo and in vitro. J Physiol (Lond) 490:703-711.

Fukazawa Y, Saitoh Y, Ozawa F, Ohta Y, Mizuno K, Inokuchi K (2003) Hippocampal LTP is accompanied by enhanced F-actin content within the dendritic spine that is essential for late LTP maintenance in vivo. Neuron 38:447-460.

GuzowskiJF, Mcnaughton BL, Barnes CA, Worley PF (1999) Environment- specific expression of the immediate-early gene Arc in hippocampal neuronal ensembles. Nat Neurosci 2:1120-1124.

Guzowski JF, Lyford GL, Stevenson GD, Houston FP, McGaugh JL, Worley PF, Barnes CA (2000) Inhibition of activity-dependent arc protein expression in the rat hippocampus impairs the maintenance of long-term potentiation and the consolidation of long-term memory. J Neurosci 20:3993-4001.

Guzowski JF, Miyashita T, Chawla MK, Sanderson J, Maes LI, Houston FP, Lipa P, McNaughton BL, Worley PF, Barnes CA (2006) Recent behavioral history modifies coupling between cell activity and Arc gene transcription in hippocampal CA1 neurons. Proc Natl Acad Sci USA 103:1077-1082.

Halpain S (2000) Actin and the agile spine: how and why do dendritic spines dance? Trends Neurosci 23:141-146.

Harris KM, Fiala JC, Ostroff L (2003) Structural changes at dendritic spine synapses during long-term potentiation. Philos Trans R Soc Lond B Biol Sci 358:745-748.

Havik B, Rokke H, Bardsen K, Davanger S, Bramham CR (2003) Bursts of high-frequency stimulation trigger rapid delivery of pre-existing alphaCaMKII mRNA to synapses: a mechanism in dendritic protein synthesis during long-term potentiation in adult awake rats. Eur J Neurosci 17:2679-2689.

Huang F, Chotiner JK, Steward O (2005) The mRNA for elongation factor lalpha is localized in dendrites and translated in response to treatments that induce long-term depression. J Neurosci 25:7199-7209.

Huang YY, Bach ME, Lipp HP, Zhuo M, Wolfer DP, Hawkins RD, Schoonjans L, Kandel ER, Godfraind JM, Mulligan R, Collen D, Carmeliet P (1996) Mice lacking the gene encoding tissue-type plasminogen activator show a selective interference with late-phase long-term potentiation in both Schaffer collateral and mossy fiber pathways. Proc Natl Acad Sci USA 93:8699-8704.

Hughes PE, Alexi T, Dragunow M (1997) Cycloheximide phase-shifts, but does not prevent, de novo Krox-24 protein expression. NeuroReport 8:3263-3266.

Husi H, Ward MA, Choudhary JS, Blackstock WP, Grant SG (2000) Proteomic analysis of NMDA receptor-adhesion protein signaling complexes. Nat Neurosci 3:661-669.

Hyman SE, Malenka RC, Nestler EJ (2006) Neural mechanisms of addiction: the role of reward-related learning and memory. Annu Rev Neurosci 29:565-598.

Jones MW, Errington ML, French PJ, Fine A, Bliss TV, Garel S, Charnay P, Bozon B, Laroche S, Davis S (2001) A requirement for the immediate early gene Zif268 in the expression of late LTP and long-term memories. Nat Neurosci 4:289-296.

Ju W, Morishita W, Tsui J, Gaietta G, Deerinck TJ, Adams SR, Garner CC, Tsien RY, Ellisman MH, Malenka RC (2004) Activity-dependent regulation of dendritic synthesis and trafficking of AMPA receptors. Nat Neurosci 7:244-253.

Kanai Y, Dohmae N, Hirokawa N (2004) Kinesin transports RNA: isolation and characterization of an RNA-transporting granule. Neuron 43:513-525.

Kang H, Welcher AA, Shelton D, Schuman EM (1997) Neurotrophins and time: different roles for TrkB signaling in hippocampal long-term potentiation. Neuron 19:653-664.

Kanhema T, Dagestad G, Panja D, Tiron A, Messaoudi E, Havik B, Ying SW, Nairn AC, Sonenberg N, Bramham CR (2006) Dual regulation of translation initiation and peptide chain elongation during BDNF-induced LTP in vivo: evidence for compartment-specific translation control. J Neurochem 19:1328-1337.

Karpova A, Mikhaylova M, Thomas U, Knopfel T, Behnisch T (2006) Involvement of protein synthesis and degradation in long-term potentiation of Schaffer collateral CA1 synapses. J Neurosci 26:4949-4955.

Kelly MP, Deadwyler SA (2003) Experience-dependent regulation of the immediate-early gene arc differs across brain regions. J Neurosci 23:6443-6451.

Kelly MT, Yao Y, Sondhi R, Sacktor TC (2007) Actin polymerization regulates the synthesis of PKMzeta in LTP. Neuropharmacology 52:41-45.

Kesner RP, Lee I, Gilbert P (2004) A behavioral assessment of hippocampal function based on a subregional analysis. Rev Neurosci 15:333-351.

Kim CH, Lisman JE (1999) A role of actin filament in synaptic transmission and long-term potentiation. J Neurosci 19:4314-4324. 
Klann E, Dever TE (2004) Biochemical mechanisms for translational regulation in synaptic plasticity. Nat Rev Neurosci 5:931-942.

Kuipers SD, Bramham CR (2006) Brain-derived neurotrophic factor mechanisms and function in adult synaptic plasticity: new insights and implications for therapy. Curr Opin Drug Discov Devel 9:580-586.

Lee I, Hunsaker MR, Kesner RP (2005) The role of hippocampal subregions in detecting spatial novelty. Behav Neurosci 119:145-153.

Ling DS, Benardo LS, Sacktor TC (2006) Protein kinase Mzeta enhances excitatory synaptic transmission by increasing the number of active postsynaptic AMPA receptors. Hippocampus 16:443-452.

Link W, Konietzko U, Kauselmann G, Krug M, Schwanke B, Frey U, Kuhl D (1995) Somatodendritic expression of an immediate early gene is regulated by synaptic activity. Proc Natl Acad Sci USA 92:5734-5738.

Lyford GL, Yamagata K, Kaufmann WE, Barnes CA, Sanders LK, Copeland NG, Gilbert DJ, Jenkins NA, Lanahan AA, Worley PF (1995) Arc, a growth factor and activity-regulated gene, encodes a novel cytoskeletonassociated protein that is enriched in neuronal dendrites. Neuron 14:433-445.

Matsuzaki M, Honkura N, Ellis-Davies GC, Kasai H (2004) Structural basis of long-term potentiation in single dendritic spines. Nature 429:761-766.

McHugh TJ, Jones MW, Quinn JJ, Balthasar N, Coppari R, Elmquist JK, Lowell BB, Fanselow MS, Wilson MA, Tonegawa S (2007) Dentate gyrus NMDA receptors mediate rapid pattern separation in the hippocampal network. Science 317:94-99.

Meng Y, Zhang Y, Tregoubov V, Janus C, Cruz L, Jackson M, Lu WY, MacDonald JF, Wang JY, Falls DL, Jia Z (2002) Abnormal spine morphology and enhanced LTP in LIMK-1 knockout mice. Neuron 35:121-133.

Messaoudi E, Ying SW, Kanhema T, Croll SD, Bramham CR (2002) BDNF triggers transcription-dependent, late-phase LTP in vivo. J Neurosci 22:7453-7461.

Miller S, Yasuda M, Coats JK, Jones Y, Martone ME, Mayford M (2002) Disruption of dendritic translation of CaMKIIalpha impairs stabilization of synaptic plasticity and memory consolidation. Neuron 36:507-519.

Moga DE, Calhoun ME, Chowdhury A, Worley P, Morrison JH, Shapiro ML (2004) Activity-regulated cytoskeletal-associated protein is localized to recently activated excitatory synapses. Neuroscience 125:7-11.

Morris RG (2006) Elements of a neurobiological theory of hippocampal function: the role of synaptic plasticity, synaptic tagging and schemas. Eur J Neurosci 23:2829-2846.

Nestler EJ, Carlezon Jr WA (2006) The mesolimbic dopamine reward circuit in depression. Biol Psychiatry 59:1151-1159.

Nguyen PV, Kandel ER (1996) A macromolecular synthesis-dependent late phase of long-term potentiation requiring cAMP in the medial perforant pathway of rat hippocampal slices. J Neurosci 16:3189-3198.

Pastalkova E, Serrano P, Pinkhasova D, Wallace E, Fenton AA, Sacktor TC (2006) Storage of spatial information by the maintenance mechanism of LTP. Science 313:1141-1144.

Plath N, Ohana O, Dammermann B, Errington ML, Schmitz D, Gross C, Mao X, Engelsberg A, Mahlke C, Welzl H, Kobalz U, Stawrakakis A, Fernandez E, Waltereit R, Bick-Sander A, Therstappen E, Cooke SF, Blanquet V, Wurst W, Salmen B, et al. (2006) Arc/Arg3.1 is essential for the consolidation of synaptic plasticity and memories. Neuron 52:437-444.

Ramirez-Amaya V, Vazdarjanova A, Mikhael D, Rosi S, Worley PF, Barnes CA (2005) Spatial exploration-induced Arc mRNA and protein expression: evidence for selective, network-specific reactivation. J Neurosci 25:1761-1768.

Rao VR, Pintchovski SA, Chin J, Peebles CL, Mitra S, Finkbeiner S (2006) AMPA receptors regulate transcription of the plasticity-related immediate-early gene Arc. Nat Neurosci 9:887-895.

Rex CS, Lin CY, Kramar EA, Chen LY, Gall CM, Lynch G (2007) Brain- derived neurotrophic factor promotes long-term potentiation-related cytoskeletal changes in adult hippocampus. J Neurosci 27:3017-3029.

Rial Verde EM, Lee-Osbourne J, Worley PF, Malinow R, Cline HT (2006) Increased expression of the immediate-early gene arc/arg3.1 reduces AMPA receptor-mediated synaptic transmission. Neuron 52:461-474.

Rodriguez JJ, Davies HA, Silva AT, De Souza IE, Peddie CJ, Colyer FM, Lancashire CL, Fine A, Errington ML, Bliss TV, Stewart MG (2005) Long-term potentiation in the rat dentate gyrus is associated with enhanced Arc/Arg3.1 protein expression in spines, dendrites and glia. Eur J Neurosci 21:2384-2396.

Routtenberg A, Rekart JL (2005) Post-translational protein modification as the substrate for long-lasting memory. Trends Neurosci 28:12-19.

Sarmiere PD, Bamburg JR (2004) Regulation of the neuronal actin cytoskeleton by ADF/cofilin. J Neurobiol 58:103-117.

Scheetz AJ, Nairn AC, Constantine-Paton M (2000) NMDA receptormediated control of protein synthesis at developing synapses. Nat Neurosci 3:211-216.

Schratt GM, Nigh EA, Chen WG, Hu L, Greenberg ME (2004) BDNF regulates the translation of a select group of mRNAs by a mammalian target of rapamycin-phosphatidylinositol 3-kinase-dependent pathway during neuronal development. J Neurosci 24:7366-7377.

Shepherd JD, Rumbaugh G, Wu J, Chowdhury S, Plath N, Kuhl D, Huganir RL, Worley PF (2006) Arc/Arg3.1 mediates homeostatic synaptic scaling of AMPA receptors. Neuron 52:475-484.

Steward O, Halpain S (1999) Lamina-specific synaptic activation causes domain-specific alterations in dendritic immunostaining for MAP2 and CAM kinase II. J Neurosci 19:7834-7845.

Steward O, Worley PF (2001a) A cellular mechanism for targeting newly synthesized mRNAs to synaptic sites on dendrites. Proc Natl Acad Sci USA 98:7062-7068.

Steward O, Worley PF (2001b) Selective targeting of newly synthesized Arc mRNA to active synapses requires NMDA receptor activation. Neuron 30:227-240.

Wallace CS, Lyford GL, Worley PF, Steward O (1998) Differential intracellular sorting of immediate early gene mRNAs depends on signals in the mRNA sequence. J Neurosci 18:26-35.

Weeks AC, Ivanco TL, LeBoutillier JC, Racine RJ, Petit TL (2001) Sequential changes in the synaptic structural profile following long-term potentiation in the rat dentate gyrus. III. Long-term maintenance phase. Synapse 40:74-84.

Wibrand K, Messaoudi E, Havik B, Steenslid V, Lovlie R, Steen VM, Bramham CR (2006) Identification of genes co-upregulated with Arc during BDNF-induced long-term potentiation in adult rat dentate gyrus in vivo. Eur J Neurosci 23:1501-1511.

Yang N, Higuchi O, Ohashi K, Nagata K, Wada A, Kangawa K, Nishida E, Mizuno K (1998) Cofilin phosphorylation by LIM-kinase 1 and its role in Rac-mediated actin reorganization. Nature 393:809-812.

Yin Y, Edelman GM, Vanderklish PW (2002) The brain-derived neurotrophic factor enhances synthesis of Arc in synaptoneurosomes. Proc Natl Acad Sci USA 99:2368-2373.

Ying SW, Futter M, Rosenblum K, Webber MJ, Hunt SP, Bliss TV, Bramham CR (2002) Brain-derived neurotrophic factor induces long-term potentiation in intact adult hippocampus: requirement for ERK activation coupled to CREB and upregulation of Arc synthesis. J Neurosci 22:1532-1540.

Zhou Q, Xiao M, Nicoll RA (2001) Contribution of cytoskeleton to the internalization of AMPA receptors. Proc Natl Acad Sci USA 98:1261-1266.

Zito K, Knott G, Shepherd GM, Shenolikar S, Svoboda K (2004) Induction of spine growth and synapse formation by regulation of the spine actin cytoskeleton. Neuron 44:321-334. 